EL MUHASABA: Jurnal Akuntansi (e-Journal)

Volume 12 , No. 2, Tahun 2021

P ISSN: 2086-1249 ; E ISSN: 2442-8922

\title{
KUALITAS LAPORAN KEUANGAN PEMERINTAH DAERAH DI INDONESIA : LITERATURE REVIEW
}

\author{
Farah Faadillah Herindraningrum ${ }^{1}$, Indrawati Yuhertiana ${ }^{2}$ \\ Universitas Pembangunan Nasional "Veteran" Jawa Timur1,2 \\ Jl. Raya Rungkut Madya, 60294, Indonesia \\ e-mail: farah.faadillah14@gmail.com 1 \\ yuhertiana@upnjatim.ac.id²
}

\begin{abstract}
This literature review aims to map research on the quality of local government financial reports in Indonesia and to see how the role of accountability and transparency factors in the quality of local government reports in Indonesia. This research method uses SLR (Systematic Literature Review). Analysis of data by mapping 28 selected journals from 2015 to 2020 in the Google Scholar database. The results of this research show factors affecting the quality of the Indonesian government's financial reports, namely: human resource competence, Information Technology, Accountability, Transportation, Audit Quality, Accounting System, Accounting Procedure, Accounting Standards, and Internal Management with quantitative research type, Qualitative, literature review, and mix method. The most frequently investigated factor is the competence of human resources as much as 15 times the type of research that is widely used is quantitative research as much as 20. This research also shows that the accountability and transparency of financial reporting have a significant effect on the quality of financial reporting of local governments in Indonesia.
\end{abstract}

Keywords: Financial Report; Accountability; Transparency

Abstrak

Literature Review ini bertujuan untuk memetakan penelitian kualitas laporan keuangan pemerintah daerah di Indonesia dan untuk melihat bagaimana peran faktor akuntabilitas dan transparansi pada kualitas laporan pemerintah daerah di Indonesia. Metode penelitian ini menggunakan SLR (Systematic Literature Review). Analisis data dengan memetakan 28 jurnal terpilih dari tahun 2015 hingga tahun 2020 di database Google Scholar. Hasil penelitian ini menunjukkan faktor-faktor yang memengaruhi kualitas laporan keuangan pemerintah daerah di Indonesia, yaitu: Kompetensi sumber daya manusia, Teknologi Informasi, Akuntabilitas, Transparansi, Kualitas Audit, Sistem Akuntansi, Prosedur Akuntansi, Standar Akuntansi, dan Pengendalian Internal dengan jenis penelitian kuantitatif, kualitatif, literature review, dan mix method. Faktor paling banyak diteliti adalah kompetensi sumber daya manusia sebanyak 15 kali dengan jenis penelitian yang banyak digunakan adalah penelitian kuantitatif sebanyak 20. Penelitian ini juga menunjukkan bahwa akuntabilitas dan transparansi pelaporan keuangan memiliki pengaruh yang signifikan terhadap kualitas pelaporan keuangan pemerintah daerah di Indonesia.

Kata kunci: Laporan Keuangan; Akuntabilitas; Transparansi

\section{PENDAHULUAN}

Dalam era reformasi ini di setiap negara pasti membutuhkan pemerintah yang baik atau yang biasa disebut dengan Good Government Governance di seluruh dunia, termasuk Indonesia. Pemberlakuan otonomi daerah merupakan bagian dari reformasi kehidupan dari pemerintah pusat ke pemerintah daerah. Otonomi daerah mengubah 
Farah Faadillah Herindraningrum dan Indrawati Yuhertiana : Kualitas Laporan Keuangan Pemerintah Daerah Di Indonesia : Literature Review

kebijakan pemerintah pusat terhadap segelintir bidang menjadi kebijakan daerah, termasuk kebijakan pengelolaan fiskal daerah (Permadi, 2013).

Dalam proses penerapan good governance, Rohman menjelaskan dalam Modul LAN 2000 bahwa pemerintah terus berbenah untuk meningkatkan transparansi dan akuntabilitas pengelolaan keuangan pusat/daerah, salah satu nya dengan penyempurnaan sistem akuntansi dan administrasi secara menyeluruh (Permadi, 2013). Perbaikan sistem akuntansi juga mempengaruhi kualitas laporan keuangan yang dibuat.

Perkembangan akuntansi sektor publik Indonesia semakin pesat, terutama dalam implementasi kebijakan otonomi daerah. Reformasi akuntansi di sektor publik ditandai dengan transisi dari akuntansi kas ke akuntansi akrual. Reformasi akuntansi inipun ditandai juga dengan diterbitkannya undang-undang yaitu, Undang-Undang Nomor 17 tahun 2003 tentang Keuangan Negara, Undang-Undang Nomor 1 tahun 2004 tentang Perbendaharaan Negara dan Undang- Undang Nomor 15 Tahun 2004 tentang Pemeriksaaan Penggelolaan dan Tanggungjawab Keuangan Negara (Harahap, 2012).

Adanya reformasi akuntansi sektor publik dari kas menjadi akuntansi akrual telah diiringi dengan perubahan dalam beberapa aspek, seperti adanya standar dan metode akuntansi. Standar akuntansi pemerintah di Indonesia memang baru diawali dengan keluarnya Peraturan Pemerintah No.71 Tahun 2010 tentang Standar Akuntansi Pemerintahan (Fatonah, 2017). Perubahan akuntansi ini diharapkan dapat menyeimbangkan reformasi akuntansi sektor publik, meningkatkan akuntabilitas, dan meningkatkan output.

Output berupa laporan keuangan. Output akuntansi sektor publik adalah laporan keuangan pemerintah pusat dan daerah. Laporan keuangan adalah sarana dimana bisnis (dalam hal ini pemerintah) bertanggung jawab kepada masyarakat umum atas kinerja keuangannya. Pemerintah harus mampu menyajikan laporan keuangan yang berisi informasi keuangan berkualitas baik. Standar akuntansi pemerintahan menetapkan bahwa laporan keuangan yang berkualitas memenuhi karakteristik relevansi, reliabilitas, komparabilitas dan kejelasan (Fauzi, 2019). Karena banyak faktor, laporan keuangan ini mengandung informasi berkualitas tinggi, misalnya akuntabilitas dan transparansi laporan keuangan.

Akuntabilitas adalah salah satu bentuk tanggung jawab atas berhasil tidaknya suatu misi organisasi untuk mencapai tujuan dan sasaran tertentu melalui sarana pertanggungjawaban yang dijalankan secara berkala. Akuntabilitas dan transparansi dalam pengelolaan keuangan pemerintah pusat dan daerah merupakan tujuan penting reformasi akuntansi dan administrasi sektor publik (Setyowati et al., 2016). Akuntabilitas publik keuangan daerah adalah pemberian informasi dan pengungkapan (disclosure) atas aktivitas dan kinerja keuangan daereah kepada semua pihak yang berkepentingan (stakeholder) sehingga hak-hak publik, yaitu hak untuk tau (right to know), hak untuk diberi informasi (right to be kept information), dan hak untuk didengar aspirasinya (right to be heard and to be listened to) dapat terpenuhi (Ginting, 2011).

Penilaian terhadap badan publik terkait diperlukan untuk mengetahui kualitas akuntabilitas keuangan negara / daerah. Salah satu ukuran akuntabilitas laporan 
Farah Faadillah Herindraningrum dan Indrawati Yuhertiana : Kualitas Laporan Keuangan Pemerintah Daerah Di Indonesia : Literature Review

keuangan berdasarkan pendapat auditor eksternal (BPK RI) atas pelaporan pemerintah. Dalam hal ini, BPK akan mengeluarkan empat jenis pemberitahuan: WTP (wajar tanpa pengecualian), WDP (wajar dengan pengecualian), TW (tidak wajar), penolakan untuk memberikan pemberitahuan atau disclaimer (disclaimer).

Transparansi diperlukan untuk memastikan bahwa pemangku kepentingan memiliki kepercayaan terhadap pengambilan keputusan dan proses perilaku lembaga pemerintah dan pengelolaannya. Suasana terbuka yang tercipta dari komunikasi yang jelas, tepat dan efektif dengan pemangku kepentingan membantu terlaksananya kegiatan secara tepat waktu dan efisien (Sari, 2012). Transparansi adalah proses demokrasi penting yang memungkinkan semua warga negara untuk melihat secara publik dan jelas tanpa harus merahasiakan kegiatan pemerintah (Ginting, 2011). Inti dari sistem ini adalah kemampuan untuk mengumpulkan informasi melalui akuntabilitas pejabat atas kegiatan yang dilakukan oleh semua warga negara.

Kualitas Laporan Pemerintahan Daerah yang baik (good governance) tidak hanya ditentukan oleh akuntabilitas, transparansi, partisipasi masyarakat dan supremasi hukum. Namun, kualitas tata kelola yang baik tergantung pada faktor-faktor lain seperti daya tanggap, efektivitas kesetaraan berbasis konsensus, efisiensi dan visi strategis. Hal ini sejalan dengan karakteristik good governance UNDP dan Bank Dunia (Ginting, 2011). Karena banyaknya faktor yang mempengaruhi kualitas pelaporan pemerintah daerah, kualitas pelaporan pemerintah daerah menghasilkan kualitas yang berbeda di tingkat nasional dan daerah/kota. Kualitas laporan pemerintah daerah dilihat dalam Data Hasil Pemeriksaan BPK RI, yang dimana pada tahun 2018 dari 34 pemerintah provinsi, sebanyak 33 LKPD (97\%) memperoleh opini WTP dan 1 LKPD (3\%) mendapat opini WDP. Dari 415 pemerintah kabupaten, sebanyak 298 LKPD (72\%) mendapat opini WTP dan 99 LKPD (24\%) dengan opini WDP. Sedangkan dari 93 pemerintah kota, sebanyak 80 LKPD (86\%) memperoleh opini WTP dan 13 LKPD (14\%) dengan opini WDP (BPK RI).

Dilihat dari data tahun 2018, kualitas pelaporan keuangan pemerintah daerah meningkat. Oleh karena itu, literature review ini ditujukan untuk pemetaan survei kualitas pelaporan keuangan pemerintah daerah di Indonesia. Pemetaan ini disesuaikan dari setiap penelitian dengan faktor yang berbeda ketika menilai kualitas laporan dari pemerintah daerah di Indonesia. Tujuan lain dari literature ini adalah untuk melihat bagaimana akuntabilitas dan transparansi berperan dalam kualitas laporan pemerintah daerah Indonesia. Dengan kata lain, pemetaan studi kualitas pelaporan keuangan pemerintah Indonesia dan studi terkait disesuaikan dengan masing-masing studi, dengan fokus pada faktor yang berbeda seperti akuntabilitas dan transparansi.

\section{METODE}

Penelitian ini menggunakan pendekatan literature review dengan metode SLR (Systematic Literature Review). Systematic Literature Review (SLR) dalam bahasa indonesia disebut tinjauan pustaka sistematis adalah metode literature review yang mengidentifikasi, menilai, dan menginterpretasi seluruh temuan-temuan pada suatu topik penelitian, untuk menjawab pertanyaan penelitian (research question) yang telah 
Farah Faadillah Herindraningrum dan Indrawati Yuhertiana : Kualitas Laporan Keuangan Pemerintah Daerah Di Indonesia : Literature Review

ditetapkan sebelumnya (Wahono, 2013). Tidak hanya itu, SLR membantu mengembangkan pemikiran kritis dan program penelitian masa depan dari perspektif bidang penelitian baru seperti akuntansi PV (Douglas \& Sutton, 2010). Pendekatan SLR terutama didasarkan pada struktur logis yang menetapkan analisis data dan aturan interpretasi. Dengan mendokumentasikan secara rinci langkah-langkah analisis dan evaluasi data, SLR menggunakan pencarian transparan dan strategi pengambilan sampel untuk memastikan replikasi (Douglas \& Sutton, 2010).

Secara umum tahapan melakukan SLR terdiri dari 3 bagian besar: Planning, Conducting dan Reporting. Pada tahap pertama yaitu Planning. Dalam Planning dibagi 2 tahap lagi antara lain : Formulate the Review's Research Question dan Develop the Review's Protocol. Research Question (RQ) adalah bagian awal dan dasar berjalannya SLR. RQ digunakan untuk menuntun proses pencarian dan ekstraksi literatur. Formulasi RQ didasarkan pada lima elemen yang terkenal dengan sebutan PICOC:

1. Population $(\mathrm{P})$ : Target group dari investigasi berupa akuntansi publik dan reformasi akuntansi.

2. Intervention (I): Aspek detail dari investigasi, atau isu yang menarik bagi peneliti yaitu berupa kualitas laporan keuangan pemerintah daerah

3. Comparison (C): Aspek dari investigasi dimana Intervention (I) akan dibandingkan.

4. Outcomes (O): Efek dan hasil dari Intervention (I) salah satunya faktor yang memengaruhi kualitas laporan keuangan

5. Context $(\mathrm{C})$ : Setting dan lingkungan dari investigasi berupa pemerintah daerah di Indonesia

Setelah itu adalah menyusun protokol SLR (SLR Protocol). Protokol SLR adalah rencana yang berisi prosedur dan metode yang kita pilih dalam melakukan SLR. Tahap kedua adalah Conducting. Pada tahap ini dibagi 5 sub tahap, antara lain : Indetify the Relevant Literature, Perform Selection of Primary Studies, Perform Data Extraction, Assess Studies' Quality, dan Conduct Synthesis of Evidence. Tahapan conduting adalah tahapan yang berisi pelaksanaan dari SLR. Dimulai dari penentuan keyword pencarian literatur (search string). Pencarian topik pada tahap Planning menemukan literatur terkait "Kualitas Laporan Keuangan Pemerintah Daerah", "Akuntabilitas Laporan Keuangan", dan "Transparansi Laporan Keuangan". Kemudian langkah berikutnya adalah penentuan sumber (digital library) dari pencarian literatur. Karena literatur yang kita kumpulkan akan sangat banyak, mungkin ratusan atau ribuan paper, maka disarankan untuk menggunakan tool software untuk mempermudah kita mengelola literatur seperti Mendeley.

Ketika semua literatur sudah siap, langkah selanjutnya adalah memilih yang benar. Untuk menyederhanakan proses ini, disarankan untuk membuat kriteria (kriteria inklusi dan kriteria pengecualian) yang berfungsi sebagai filter untuk memilih dan menolak dokumen. Kami kemudian menemukan 243 jurnal terkait judul yang dicari oleh penulis di database Google Scholar dari 2015 hingga 2020. Pemilihan 28 artikel dari 243 jurnal terkait didasarkan dengan kriteria : 1 . Artikel memuat pembahasan terkait faktor yang memengaruhi kualitas laporan keuangan lebih dari satu, 2. Sesuai filtrasi penulis. 
Farah Faadillah Herindraningrum dan Indrawati Yuhertiana : Kualitas Laporan Keuangan Pemerintah Daerah Di Indonesia : Literature Review

Setelah mendapatkan literatur yang diperlukan, langkah terakhir adalah mengekstrak data dan mensintesis temuan dari literatur yang dipilih (sintesis bukti). Dari 28 jurnal yang diambil, penulis menulis kertas kerja/ringkasan untuk 28 jurnal terpilih. Ringkasan yang berisi gambaran umum dari seluruh jurnal yang dipilih, sehingga penulis dapat dengan mudah menyelesaikan artikel ini tanpa harus membuka dan membaca setiap jurnal yang dipilih. Tujuan utama pengumpulan data adalah untuk menganalisis dan mengevaluasi hasil studi yang berbeda dari sumber yang berbeda dan untuk memilih metode yang paling tepat untuk mengintegrasikan penjelasan dan interpretasi hasil (Wahono, 2013).

Di tahap terakhir ada Reporting. Tahap ini dibagi 3 sub tahap, yaitu : Write Up the SLR Paper dan Choose the Right Journal. Reporting adalah tahapan penulisan hasil SLR dalam bentuk tulisan, baik untuk dipublikasikan dalam bentuk paper ke jurnal ilmiah atau untuk menyusun Bab 2 tentang Literature Review dari skripsi/tesis/disertasi kita (Wahono, 2013). Struktur penulisan dari SLR biasanya terdiri dari 3 bagian besar, yaitu: Pendahuluan (Introduction), Utama (Main Body) dan Kesimpulan (Conclusion). Bagian Pendahuluan akan berisi latar belakang dan landasan mengapa SLR pada suatu topik itu penting dan harus dilakukan. Sedangkan Bagian Utama akan berisi protokol SLR, hasil analisis dan sintesis temuan, serta diakhiri dengan diskusi yang membahas implikasi dari hasil SLR. Bagian Kesimpulan akan berisi rangkuman dari temuan yang kita dapatkan, sesuai dengan RQ yang kita tetapkan di depan. Nah pada tahap inilah, dari tahapan SLR digunakan untu menulis artikel "Kualitas Laporan Keuangan Pemerintah Daerah di Indonesia"

\section{Tahapan SLR}

Planning :

1. Memformulasikan Research Question

2. Mengembangkan protokol review

Conducting :

1. Mengidentifikasi literatur yang relevan

2. Melakukan seleksi studi primer

3. Melakukan ekstraksi data

4. Menilai kualitas studi

5. Melakukan sintesis bukti

Reporting :

1. Menulis artikel SLR

2. Memilih jurnal yang tepat

Gambar 1. Tahapan Systematic Literature Review

Sumber : diolah penulis 
Farah Faadillah Herindraningrum dan Indrawati Yuhertiana : Kualitas Laporan Keuangan Pemerintah Daerah Di Indonesia : Literature Review

\section{HASIL DAN PEMBAHASAN}

Ada 2.570 artikel dari sumber yang mencari artikel tentang kualitas pelaporan keuangan di database Google Scholar. Sebagian besar penelitian didasarkan pada penelitian serupa dengan menggunakan variabel yang berbeda (Yuhertiana, 2015) yang mempengaruhi kualitas laporan keuangan Indonesia.

\section{Kualitas Laporan Keuangan Pemerintah Daerah}

Laporan keuangan merupakan hasil tanggung jawab para penyusun laporan keuangan. Laporan keuangan yang disusun oleh lembaga keuangan mikro lokal merupakan hasil akuntansi sesuai dengan siklus akuntansi yang dilakukan sebelumnya: tahap identifikasi dokumen, tahap entri jurnal dan periode akuntansi untuk setiap akun (Hanaffi, 2017). Sementara itu, menurut peraturan pemerintah No. 71 Tahun 2010, entitas pelapor laporan keuangan disusun dan didefinisikan dalam laporan sesuai dengan situasi keuangan dan transaksi yang dilakukan (Hanaffi, 2017). Shahan (2008) berpendapat bahwa tujuan mendasar dari laporan keuangan adalah menyediakan informasi yang berguna untuk pengambilan keputusan (Andriyani, 2020). Bermanfaat bagi pengguna laporan keuangan pemerintah jika laporan keuangan pemerintah daerah merupakan hasil akuntansi setelah melalui suatu siklus akuntansi di pemerintah daerah.

Kualitas laporan keuangan pemerintah daerah merupakan karakteristik kualitatif laporan yang menyajikan posisi keuangan, kinerja, dan informasi lain pemerintah daerah yang dihasilkan dari akun-akun tersebut. Keputusan membuat proses (Fauzi, 2019). Di sisi lain, sesuai dengan Peraturan Pemerintah No. 71 Tahun 2010 tentang Standar Akuntansi Pemerintahan, laporan tersebut (1) dapat diandalkan, (2) relevan, (3) dapat dipahami dan, dalam beberapa kasus, merupakan laporan keuangan pemerintah. kualitas tinggi. (4) Sebanding (Setyowati et al., 2016). Kualitas laporan keuangan berpengaruh signifikan terhadap akuntabilitas. Kualitas pelaporan keuangan didedikasikan untuk tanggung jawab atau kewajiban laporan keuangan yang disiapkan. Secara umum, kualitas laporan keuangan daerah merupakan ciri kualitatif dari proses akuntansi, dimana akuntabilitas dan transparansi saling mempengaruhi. Semakin tinggi kualitas pelaporan keuangan pemerintah, semakin besar akuntabilitas dan transparansi, dan sebaliknya.

Pemetaan yang didapat dari 28 artikel menghasilkan 4 jenis penelitian yang digunakan. 4 jenis penelitian tersebut antara lain : penelitian kuantitatif, penelitian kualitatif, penelitian mix method, dan penelitian literature Review. Jenis penelitian yang banyak digunakan adalah penelitian kuantitatif sebanyak 20, sedangkan penelitian literature review sebanyak 4 , penelitian kualitatif sebanyak 1 dan penelitian mix method sebanyak 3. Mix method dapat ditemukan di penelitian milik Meiliana, A.K, Siti-Nabiha, dan Lian-Kee Phua berjudul "Transparency And Accountability In The Public Sector : Analysing The Adoption Of Accrual Accounting In Indonesia". Penelitian ini menggunakan kombinasi deskriptif dan metode analitik (Suparman et al., 2013). 
Farah Faadillah Herindraningrum dan Indrawati Yuhertiana : Kualitas Laporan Keuangan Pemerintah Daerah Di Indonesia : Literature Review

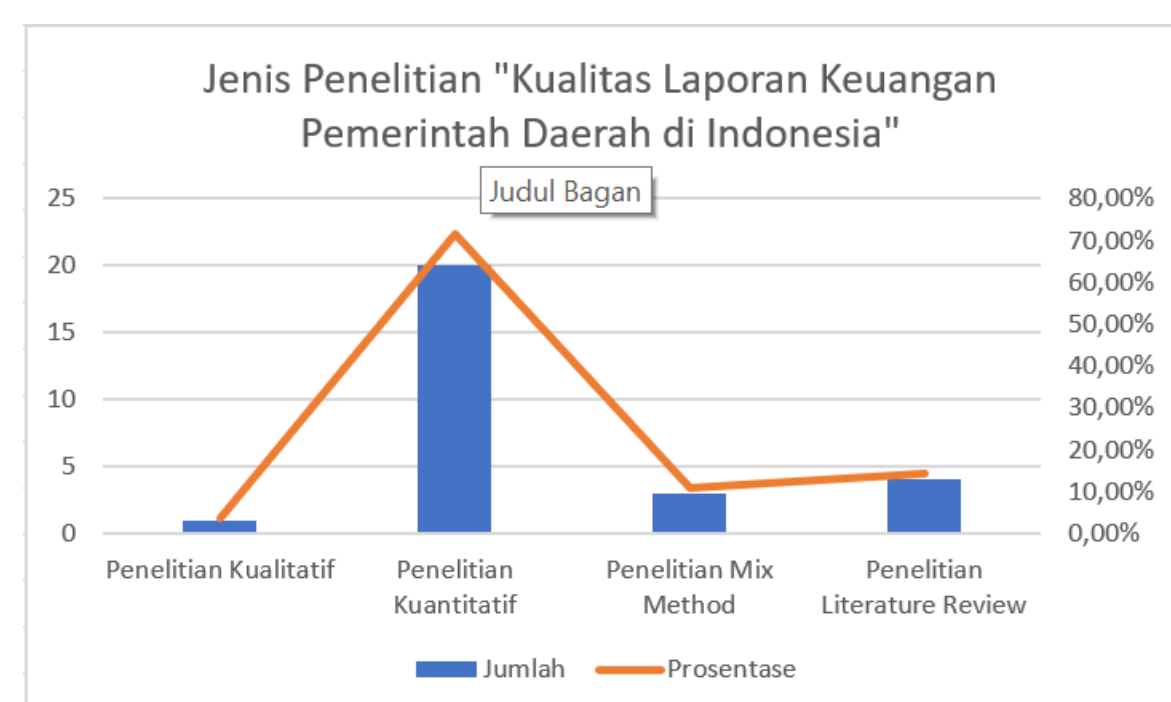

Gambar 2. Grafik jenis penelitian kualitas laporan keuangan peemrintah daerah di Indonesia

Sumber : diolah penulis

Faktor - Faktor yang Memengaruhi Kualitas Laporan Keuangan Pemerintah Daerah

Banyak penelitian yang menjelaskan faktor-faktor yang mempengaruhi kualitas laporan keuangan. Laporan keuangan pemerintah terdiri dari dua jenis laporan: laporan pemerintah pusat dan laporan pemerintah daerah. Laporan keuangan pemerintah pusat menekankan pada laporan keuangan sektor APBN. Laporan keuangan pemerintah daerah dibagi menjadi laporan keuangan pemerintah provinsi, laporan keuangan kabupaten/kota, dan laporan keuangan desa.

\section{Variabel yang Memengaruhi Kualitas Laporan Keuangan Pemerintah Daerah}

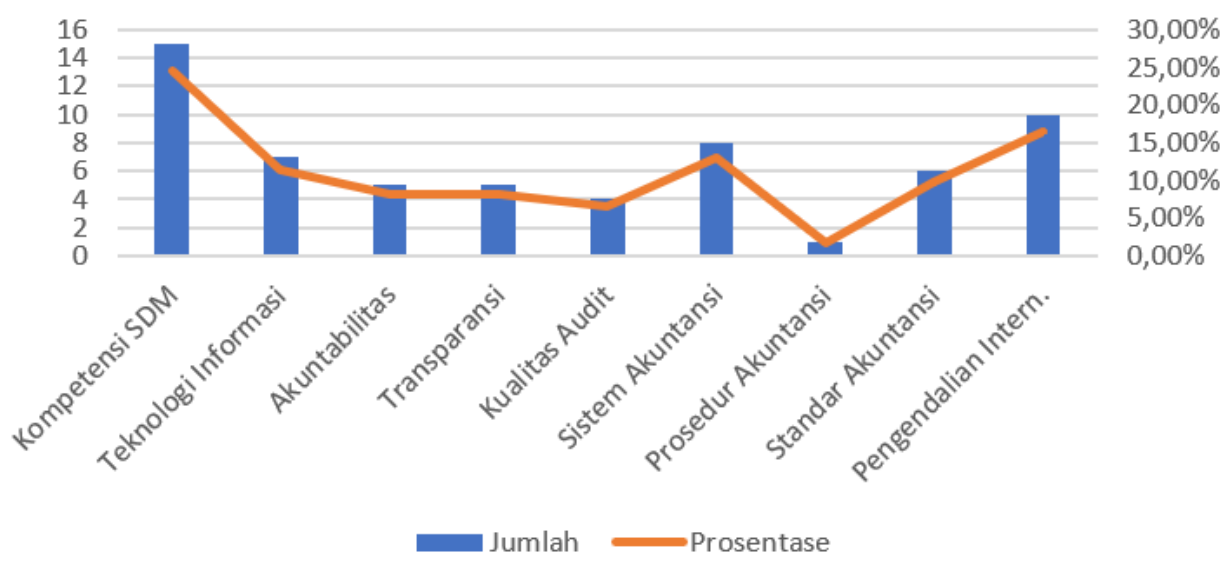

Gambar 3. Grafik variabel yang memengaruhi kualitas laporan keuangan pemerintah daerah

Sumber : diolah penulis 
Farah Faadillah Herindraningrum dan Indrawati Yuhertiana : Kualitas Laporan Keuangan Pemerintah Daerah Di Indonesia : Literature Review

Hasil pemetaan 28 penelitian sesuai filtrasi dan kriteria yang mempengaruhi kualitas laporan keuangan pemerintah daerah menunjukkan sembilan faktor yang mempengaruhi kualitas laporan keuangan pemerintah daerah Indonesia, antara lain pemerintah provinsi, kabupaten/kota, dan desa. Kesembilan faktor tersebut berdampak positif dan negatif terhadap kualitas pelaporan keuangan pemerintah daerah di Indonesia. Kesembilan faktor tersebut antara lain kompetensi SDM, teknologi informasi, akuntabilitas, transparansi, kualitas audit, sistem akuntansi, prosedur akuntansi, standar akuntansi dan pengendalian internal.

Faktor yang paling banyak diteliti adalah faktor kompetensi SDM sebanyak 15 kali. Sedangkan faktor lainnya, seperti pengendalian internal sebanyak 10 kali, teknologi informasi sebanyak 7 kali, akuntabilitas \& transparansi sebanyak 5 kali, kualitas audit sebanyak 4 kali, sistem akuntansi sebanyak 8 kali, prosedur akuntansi sebanyak 1 kali dan standar akuntansi sebanyak 6 kali.

Studi tahun 2019 oleh Zaizar Wiet Rifandi, “Penerapan aplikasi sistem keuangan desa, kapasitas sumber daya manusia, dan transparansi mempengaruhi kualitas pelaporan keuangan oleh aparat desa (Studi kasus desa di Kecamatan Wates Kabupaten Kulon Progo)". Dilihat dari judulnya, penelitian ini melihat beberapa faktor yang dapat mempengaruhi kualitas laporan keuangan daerah. Hasil penelitian menunjukkan bahwa penerapan sistem aplikasi, kapasitas sumber daya manusia, dan transparansi secara simultan berpengaruh positif terhadap kualitas pelaporan keuangan pemerintah desa. Beberapa di antaranya adalah implementasi (level) sistem keuangan desa, kapasitas dan transparansi sumber daya manusia yang masing-masing berdampak positif terhadap kualitas pelaporan keuangan pemerintah desa (Rifandi, 2019).

Banyak penelitian yang terkait dengan kualitas informasi keuangan pemerintah daerah, termasuk analisis faktor "kapasitas sumber daya manusia". Dalam judul penelitian Ranny Hanafi, "Faktor - Faktor yang Mempengaruhi Kualitas Laporan Keuangan Pemerintah Daerah (Studi Empiris Pada Satuan Kerja Perangkat Daerah Kabupaten Pati)", dianalisis beberapa faktor yang mempengaruhi kualitas pelaporan keuangan pemerintah daerah. Salah satunya adalah kapasitas sumber daya manusia memiliki pengaruh positif yang signifikan terhadap kualitas pelaporan keuangan pemerintah daerah (Hanaffi, 2017). Dalam penelitian ini, fokus tidak lagi pada laporan keuangan pemerintah kota, tetapi pada laporan keuangan pemerintah kabupaten.

Di penelitian lain milik Yuneve Nilamsari, Fatmasari Sukesti, Alwiyah Alwiyah, Ayu Noviani Hanum, dan R. Ery Wibowo berjudul "Kualitas Laporan Keuangan Pemerintah Daerah: Studi OPD Kota Semarang" disini juga menghasilkan bahwa kompetensi sumber daya manusia memengaruhi kualitas laporan keuangan pemerintah (Nilamsari et al., 2020), yang dimana objek penelitian ini pada laporan keuangan pemerintah kota. Penelitian dengan objek laporan keuangan pemerintah provinsi dilakukan oleh Febrian Cahyo Pradono dan Basukianto dengan judul “Kualitas Laporan Keuangan Pemerintah Daerah: Faktor Yang Mempengaruhi Dan Implikasi Kebijakan (Studi Pada Skpd Pemerintah Provinsi Jawa Tengah)". Dari banyaknya penelitian yang dipetakan terkait faktor "kompetensi SDM" terhadap kualitas laporan keuangn 
Farah Faadillah Herindraningrum dan Indrawati Yuhertiana : Kualitas Laporan Keuangan Pemerintah Daerah Di Indonesia : Literature Review

menandakan bahwa kualitas SDM Indonesia diberbagai daerah lebih baik (ketrampilan, pengetahuan, pengetahuan dan pengalaman SDM). Penelitian lain milik (Abdurrahim et al., 2019) juga sejalan bahwa kompetensi SDM berpengaruh positif terhadap kualitas laporan keuangan pemerintah daerah.

Dibeberapa faktor yang juga memiliki pengaruh positif terhadap kualitas laporan keuangan seperti "pengendalian internal". Penelitian yang menghasilkan pengaruh positif dari sistem pengendalian internal yaitu penelitian milik (Nilamsari et al., 2020), (Mulia, 2018) penelitian Rizki Afri Mulia ini juga menganalisis faktor kompetensi sumber daya manusia juga, (Surastiani \& Handayani, 2015), (Fauzi, 2019), (Febrian Cahyo Pradono \& Basukianto, 2015), dan (Upabayu et al., 2015). Banyaknya penelitian yang menyatakan bahwa sistem pengendalian internal berpengaruh positif terhadap kualitas laporan keuangan menandakan kebanyakan pemerintah daerah baik provinsi, kabupaten/kota bahkan desa sudah melaksankan sistem pengendalian internal yang baik.

Penelitian milik Nur Laila Yuliani dan Rahmawati Dwi Agustini yang berjudul Faktor "Yang Mempengaruhi Kualitas Laporan Keuangan Pemerintah Daerah" menghasilkan pengendalian intern tidak berpengaruh positif terhadap kualitas laporan keuangan pemerintah daerah. Ini disebabkan ada kelemahan dalam SKPD di Kabupaten Magelang. Kelemahan pengendalian intern disebabkan sub bagian akuntansi atau keuangan di SKPD belum sepenuhnya menyelenggarakan sistem akuntansi yang meliputi prosedur akuntansi penerimaan kas, pengeluaran kas, aset dan selain kas. Selain itu, transaksi yang ada dapat dilakukan tanpa adanya otorisasi dari pihak berwenang, setiap transaksi yang terjadi kurang didukung dengan bukti yang valid dan sah, dan tidak adanya pemisahan tugas dalam rangka pelaksanaan APBD (Yuliani \& Agustini, 2016).

Faktor selanjutnya adalah "teknologi informasi". Dalam penelitian milik Dyah Puri Surastiani dan Bestari Dwi Handayani berjudul "Analisis Faktor-Faktor Yang Memengaruhi Kualitas Informasi Laporan Keuangan Pemerintah Daerah" meneliti terkait SDM, pengendalian internal, dan teknologi informasi. Dalam penelitian ini menghasilkan bahwa pemanfaatan teknologi informasi tidak berpengaruh terhadap kualitas laporan keuangan (Surastiani \& Handayani, 2015). Penelitian Dyah dan Bestari ini juga didukung dengan penelitian lain, seperti : (Hanaffi, 2017), (Setyowati et al., 2016), (Indriani et al., 2018) dan (Nilamsari et al., 2020). Tidak berpengaruhnya teknologi informasi terhadap kualitas laporan keuangan disebabkan karena sistem yang ditetapkan tidak sesuai yang diinginkan, sistem masih mengalami kendala dan tampak masih asing bagi penggunannya, sehingga pengimplementasiannya menjadi sia sia dan tidak dapat mendukung penyajian laporan keuangan yang andal (Surastiani \& Handayani, 2015) yang menyebabkan kualitas laporan keuangan tidak baik.

Penelitian dari Febrian Cahyo Pradono dan Besuki berjudul "Kualitas Laporan Keuangan Pemerintah Daerah: Faktor Yang Mempengaruhi Dan Implikasi Kebijakan (Studi Pada SKPD Pemerintah Provinsi Jawa Tengah)" menunjukkan bahwa teknologi informasi berpengaruh signifikan terhadap kualitas laporan keuangan pemerintah daerah 
Farah Faadillah Herindraningrum dan Indrawati Yuhertiana : Kualitas Laporan Keuangan Pemerintah Daerah Di Indonesia : Literature Review

(Febrian Cahyo Pradono \& Basukianto, 2015). Penelitian Febrian dan Besuki juga sejalan dengan penelitian (Yuliani \& Agustini, 2016) yang menyatakan keberhasilan pengaruh teknologi informasi terhadap kualitas laporan keuangan dikarenakan sub bagian akuntansi atau keuangan telah melakukan pengolahan data transaksi keuangan dengan menggunakan software yang sesuai dengan perundang-undangan, laporan yang dihasilkan berasal dari sistem informasi yang terintegrasi, serta adanya jadwal pemeliharaan secara teratur atau peralatan yang usang atau rusak didata dan diperbaiki tepat pada waktunya (Yuliani \& Agustini, 2016).

Faktor yang memengaruhi kualitas laporan keuangan pemerintah daerah selanjutnya adalah "kualitas audit" yang dilakukan oleh Moermahadi Soerja Djanegara berjudul "Pengaruh Kualitas Audit Terhadap Kualitas Laporan Keuangan Pemerintah Daerah" yang dimana kualitas audit berpengaruh positif terhadap kualitas laporan keuangan (Djanegara, 2017), ini juga sejalan dengan penelitian milik (Adha Inapty \& Martiningsih, 2016), (Setyowati et al., 2016), dan (Hanaffi, 2017). Faktor lain yang menjadi fokus penelitian milik Sutah hariri Harahap berjudul "Implementasi Prosedur Akuntansi Berbasis Akrual dalam Penyusunan Laporan Keuangan Terhadap Kualitas Laporan Keuangan", yaitu "prosedur akuntansi". Penelitian ini menghasilkan bahwa implementasi prosedur akuntansi berbasis akrual berpengaruh positif terhadap kualitas laporan keuangan pemerintah daerah (Jati, 2019).

Faktor "sistem akuntansi" juga berpengaruh positif terhadap kualitas laporan keuangan pemerintah daerah yang sesuai penelitian milik Retno Yuliatia, Yuliansyah Yuliansyah and Yang Elvi Adelina berjudul "The implementation of accrual basis accounting by Indonesia's local governments". Penelitian tersebut menjelaskan bahwa reformasi akuntansi sektor publik (sistem akuntansi akrual) pada pemerintah daerah memengaruhi kualitas laporan keuangannya (Yuliati et al., 2019). Ini juga sejalan dengan penelitian milik (Gamayuni, 2019) dan (Karunia et al., 2019). Dan faktor terkahir adalah "standar akuntansi" yang diteliti oleh Budhi Purwanto Jati dengan judul "Pengaruh Penerapan Standar Akuntansi Pemerintahan Berbasis Akrual Terhadap Kualitas Laporan Keuangan Pemerintah Daerah" menjelaskan bahwa secara signifikan penerapan SAP Berbasis Akrual berpengaruh terhadap kualitas LKPD (Jati, 2019). Hasil ini juga sejalan dengan penelitian milik (Adha Inapty \& Martiningsih, 2016).

Faktor-faktor itu muncul disesuaikan dengan masing-masing wilayah pemerintah daerah. Jadi wilayah provinsi satu dengan provinsi lainnya akan menganalisis faktor yang berbeda beda yang memengaruhi kualitas laporan keuangan. Berlaku juga untuk wilayah pemerintahan kabupaten/kota dan wilayah pemerintahan desa.

\section{Akuntanbilitas dan Transparansi pada Kualitas Laporan Keuangan Pemerintah Daerah}

Akuntabilitas dan transparansi merupakan kriteria untuk menilai kualitas atau tidaknya laporan keuangan dalam penyusunan laporan keuangan dalam rangka melaksanakan akuntabilitas dan transparansi dalam pelaporan keuangan. Akuntabilitas sendiri merupakan konsep etika yang sangat erat kaitannya dengan pengelolaan pemerintahan (eksekutif pemerintahan, legislatif parlementer, yudikatif) dan memiliki beberapa arti. Secara khusus, ini sering digunakan sebagai sinonim dengan konsep 
Farah Faadillah Herindraningrum dan Indrawati Yuhertiana : Kualitas Laporan Keuangan Pemerintah Daerah Di Indonesia : Literature Review

seperti yang dapat dipertanggungjawabkan (responsibility), kemampuan memberikan jawaban (answeraility), yang dapat dipersalahkan (blameworthiness) dan yang mempunyai ketidakbebasan (liability) termasuk istilah lain yang mempunyai keterkaitan dengan harapan dapat menerangkannya (American Journal of Sociology, 2019). Jadi secara umum, akuntabilitas adalah bentuk pertanggungjawaban atas pemenuhan tanggungjawab yang diserahkan sesorang kepada seseorang lain dalam hal ini akuntansi atau keuangan.

Transparansi artinya pemerintahan yang baik di tingkat pusat dan daerah transparan kepada rakyat. Transparansi adalah individu, kelompok atau organisasi dalam hubungan yang bertanggung jawab tidak bertujuan untuk menekan data pada masalah tertentu, memiliki semua informasi kinerja didorong oleh kebohongan dan tidak ada motif tersembunyi (Sari, 2012). Jadi secara umum transparansi berarti keterbukaan. Artinya, laporan keuangan harus diumumkan kepada semua orang agar tidak dimanfaatkan.

Penelitian tentang akuntabilitas dan transparansi pelaporan keuangan pemerintah daerah mulai berkembang. Studi serupa secara tidak langsung menyelidiki peran akuntabilitas dan transparansi dalam pelaporan keuangan yang mempengaruhi kualitas pelaporan keuangan. Menurut penelitian Diana Sari, pengendalian internal dapat mempengaruhi transparansi laporan keuangan. Penelitian ini menunjukkan bahwa pengendalian internal berpengaruh terhadap transparansi laporan keuangan (Sari, 2012). Secara tidak langsung, transparansi juga mempengaruhi kualitas laporan keuangan. Transparansi sendiri merupakan standar pelaporan keuangan dan kualitas pelaporan keuangan pemerintah harus diperhatikan terutama dalam bentuk transparansi dalam laporan keuangan itu sendiri. Tujuan umum laporan keuangan adalah untuk memberikan informasi yang relevan tentang kondisi keuangan entitas pelapor, pelaksanaan anggaran, arus kas, dan kinerja keuangan untuk membantu pengguna membuat keputusan yang tepat dan mengevaluasi keputusan terkait alokasi sumber daya (Febrian Cahyo Pradono \& Basukianto, 2015). Salah satu manfaat bagi pengguna ini adalah bagi rakyatnya, jadi transparansi sama pentingnya dengan tanggung jawab pelaporan keuangan pemerintah untuk penggunaan keuangan pemerintah. Penelitian ini sejalan dengan penelitian (Rifandi, 2019), dan (Trimarstuti, 2019) bahwa transparansi berpengaruh positif terhadap kualitas laporan keuangan.

Penelitian terkait akuntabilitas laporan keuangan juga sudah banyak diteliti, salah satunya oleh I Made Bagus Febrianto, Gede Adi Yuniarta, dan Edy Sujana yang menjelaskan banyak faktor yang memengaruhi kualitas akuntabilitas laporan keuangan. Dijelaskan pula bahwa faktor penting yang mempengaruhi kualitas pelaporan pertanggungjawaban adalah Standar Akuntansi Pemerintahan (SAP). penelitian ini juga menjelaskan 2 pembagian komponen faktor yaitu : komponen faktor 1 dengan nama kewajaran penyajian laporan keuangan terdiri dari kesesuaian terhadap standar akuntansi pemerintah (SAP), kecukupan pengungkapan, keterbatasan sistem informasi, efektivitas sistem pengendalian internal, kepatuhan pada perundang-undangan; dan komponen faktor 2 dengan nama tata kelola pemerintahan yang baik terdiri dari 
Farah Faadillah Herindraningrum dan Indrawati Yuhertiana : Kualitas Laporan Keuangan Pemerintah Daerah Di Indonesia : Literature Review

kompetensi sumber daya manusia, budaya organisasi, komitmen manajemen, otoritas pengambilan keputusan (Febrianto et al., 2017). Penilitian tersebut juga menjelaskan bahwa Ukuran kualitas akuntabilitas keuangan pada pemerintah daerah dapat dilihat dari opini BPK RI atas penyajian laporan keuangan pemerintah (Febrianto et al., 2017).

Dua studi kasus terkait akuntabilitas dan transparansi dalam pelaporan keuangan pemerintah menunjukkan bahwa peran akuntabilitas dan transparansi penting karena keduanya merupakan bentuk pemenuhan tanggungjawab pembuat laporan keuangan yang dimana suatu laporan itu harus bisa memberikan informasi yang dapat dipertanggungjawabkan (akuntabilitas) dan bisa bermanfaat dan terbuka bagi pengguna laporan keuangan (transparansi) salah satunya masyarakat.

\section{KESIMPULAN}

Laporan keuangan pemerintah daerah adalah ouput atas proses akuntansi setelah melewati siklus akuntansi dalam lingkup pemerintah daerah yang akan bermanfaat bagi pengguana laporan keuangan pemerintah. Kualitas laporan keuangan pemerintah daerah merupakan karakteristik kualitatif sebagai hasil proses akuntansi yang dimana akuntabilitas dan transparansi saling memengaruhi. Semakin berkualitasnya laporan keuangan pemerintah maka semakin baiknya akuntabilitas dan transparansi laporan keuangan pemerintah daerah dan sebaliknya. Berdasarkan hasil penelitian, maka kesimpulan penelitian dapat diuraikan sebagai berikut:

1. Terdapat 4 jenis penelitian yang digunakan antara lain : penelitian kuantitatif, penelitian kualitatif, penelitian mix method, dan penelitian literature Review. Jenis penelitian yang banyak digunakan adalah penelitian kuantitatif sebanyak 20, sedangkan penelitian literature review sebanyak 4, penelitian kualitatif sebanyak 1 dan penelitian mix method sebanyak 3 .

2. Terdapat 9 faktor menghasilkan pengaruh positif maupun pengaruh negatif terhadap kualitas laporan keuangan pemerintah daerah di Indonesia, antara lain : Kompetensi SDM, Teknologi Informasi, Akuntabilitas, Transparansi, Kaulitas Audit, Sistem Akuntansi, Prosedur Akuntansi, Standar Akuntansi, dan Pengendalian Internal dengan faktor kompetensi SDM sebanyak 15 kali. Sedangkan faktor lainnya, seperti pengendalian internal sebanyak 10 kali, teknologi informasi sebanyak 7 kali, akuntabilitas \& transparansi sebanyak 5 kali, kualitas audit sebanyak 4 kali, sistem akuntansi sebanyak 8 kali, prosedur akuntansi sebanyak 1 kali dan standar akuntansi sebanyak 6 kali.

3. Peran akuntabilitas dan transparansi itu sangat penting karena keduanya merupakan bentuk pemenuhan tanggungjawab pembuat laporan keuangan yang dimana suatu laporan itu harus bisa memberikan informasi yang dapat dipertanggungjawabkan (akuntabilitas) dan bisa bermanfaat dan terbuka bagi pengguna laporan keuangan (transparansi) salah satunya masyarakat. 
Farah Faadillah Herindraningrum dan Indrawati Yuhertiana : Kualitas Laporan Keuangan Pemerintah Daerah Di Indonesia : Literature Review

\section{DAFTAR PUSTAKA}

Abdurrahim, Nur Hidayati, D., \& Budiarto. (2019). Implementasi Peraturan Pemerintah Nomor 71 Tahun 2010 Tentang Standar Akuntansi Pemerintahan Berbasis Akrual (Studi Pada Pemerintah Kabupaten Lombok Barat). 9, 33-36

Adha Inapty, M. A. F. B., \& Martiningsih, R. S. P. (2016). Pengaruh Penerapan Standar Akuntansi Pemerintah, Kompetensi Aparatur Dan Peran Audit Internal Terhadap Kualitas Informasi Laporan Keuangan Dengan Sistem Pengendalian Intern Sebagai Variabel Moderating (Studi Empiris pada SKPD di Pemprov NTB). Akuntabilitas, $9(1), 27-42$.

American Journal of Sociology. (2019). Pengaruh Akuntansi Auditor dan Independensi Auditor terhadap Hasil Kerja Auditor. Journal of Chemical Information and Modeling, 53(9), 1689-1699.

Andriyani, N. (2020). Jurnal akuntansi dan keuangan universitas jambi. 5(2), 132-144.

Djanegara, M. S. (2017). Pengaruh Kualitas Audit Terhadap Kualitas Laporan Keuangan Pemerintah Daerah. Jurnal Akuntansi, 21(3), 461.

Fauzi, G. R. (2019). Gelar Sarjana Ekonomi Pada Fakultas Ekonomi dan Bisnis.

Febrian Cahyo Pradono, \& Basukianto. (2015). Kualitas Laporan Keuangan Pemerintah Daerah: Faktor Yang Mempengaruhi Dan Implikasi Kebijakan (Studi Pada SKPD Pemerintah Provinsi Jawa Tengah). Jurnal Bisnis Dan Ekonomi (JBE), 22(2), 1-13.

Febrianto, I. M. B., Yuniarta, G. A., \& Sujana, E. (2017). Kualitas Akuntabilitas Keuangan Pada Satuan Kerja Perangkat Daerah ( SKPD ) e-journal S1 Ak Universitas Pendidikan Ganesha. JIMAT (Jurnal Ilmiah Mahasiswa Akuntansi) Undiksha, 8(2).

Gamayuni, R. R. (2019). the Initial Implementation of Accrual Based Accounting, the Effect on Performance and Financial Reporting Quality At Local Governments in Indonesia. Ekspansi: Jurnal Ekonomi, Keuangan, Perbankan Dan Akuntansi, 11(1), 13.

Ginting, A. (2011). Hard Milling of Hardened Tool Steel: Tool Wear and Tool Life. Jurnal Sistem Teknik Industri, 7(4), 96-99.

Hanaffi, R. (2017). Faktor-faktor yang mempengaruhi kualitas laporan keuangan pemerintah daerah (studi empiris pada Satuan Kerja Perangkat Daerah Kabupaten Pati). Jurnal Institut Agama Islam Negeri Surakarta. 12, 25-27.

Harahap, S. H. (2012). Implementasi Prosedur Akuntansi Berbasis AKrual dalam Penyusunan Laporan Keuangan Terhadap Kualitas Laporan Keuangan. 66, 37-39.

Indriani, M., Mulyany, R., Nadirsyah, N., \& Munandar, W. (2018). Readiness of Local Government in the Implementation of Accrual Accounting: The Case of Local Government in Aceh, Indonesia. Jurnal Dinamika Akuntansi Dan Bisnis, 5(1), 87-100. 
Farah Faadillah Herindraningrum dan Indrawati Yuhertiana : Kualitas Laporan Keuangan Pemerintah Daerah Di Indonesia : Literature Review

Jati, B. P. (2019). Pengaruh Penerapan Standar Akuntansi Pemerintahan Berbasis Akrual Terhadap Kualitas Laporan Keuangan Pemerintah Daerah. Wahana, 22(1), 1-14.

Karunia, A. P., Payamta, P., \& Sutaryo, S. (2019). The Implementation of Accrual-based Accounting in Indonesian Government: Has Local Government Financial Statement Quality Improved? Journal of Accounting and Investment, 20(2). https://doi.org/10.18196/jai.2002115

Mulia, R. A. (2018). J urnal El-Riyasah, Volume 9 Nomor 1 Tahun 2018 Rizki. 9, 7-21.

Nilamsari, Y., Sukesti, F., Alwiyah, A., Hanum, A. N., \& Ery, R. (2020). Kualitas Laporan Keuangan Pemerintah Daerah: Studi OPD Kota Semarang. 10(2), 85-94.

Permadi, A. D. (2013). Pengaruh Penerapan Sistem Akuntansi Keuangan Pemerintah Daerah Terhadap Kualitas Laporan Keuangan Pemerintah Daerah. Skripsi, 1-137.

Rifandi, Z. W. (2019). Pengaruh Implementasi Aplikasi Sistem Keuangan Desa, Kompetensi Sumber Daya Manusia, Dan Transparansi Terhadap Kualitas Laporan Keuangan Pemerintah Desa. Jurnal Riset Akuntansi Tirtayasa, 04(01), 1-17.

Sari, D. (2012). Pengaruh Pengendalian Internal Terhadap Transparansi Laporan Keuangan Pemerintah Daerah. Prosiding Seminar Nasional Akuntansi \& Bisnis, 718727.

Setyowati, L., Isthika, W., \& Pratiwi, R. D. (2016). Faktor-Faktor Yang Mempengaruhi Kualitas Laporan Keuangan Pemerintah Daerah Kota Semarang. Kinerja, 20(2), 179. https://doi.org/10.24002/kinerja.v20i2.843

Suparman, M., Batam, U. I., \& Phua, L. K. (2013). Transparency And Accountability In The Public Sector: Analysing. 2nd A4-PFM Conference TRANSPARENCY AND ACCOUNTABILITY IN THE PUBLIC SECTOR : October.

Surastiani, D. P., \& Handayani, B. dwi. (2015). Analisis Faktor-Faktor Yang Memengaruhi Kualitas Informasi Laporan Keuangan Pemerintah Daerah. 6.

Trimarstuti, J. (2019). Transparency and Public Accountability through Public Sector Accounting: The Use of 'Value For Money'Concept in Indonesia. International Journal of Engineering Technology and Natural Sciences, 1(1), 30-33.

Upabayu, I. P., Mahaputra, R., \& Putra, I. W. (2015). Analisis Faktor-Faktor Yang Mempengaruhi Kualitas Informasi Laporan Keuangan Pemerintah Daerah. Jurnal Dinamika Akuntansi, 7(2), 139-149.

Yuhertiana, I. (2015). Behavioural public sector accounting research in Indonesia: a literature review. Malaysian Accounting Review, 14(1), 50-64.

Yuliani, N. L., \& Agustini, R. D. (2016). Faktor Yang Mempengaruhi Kualitas Laporan Keuangan Pemerintah Daerah. Bisnis \& Ekonomi, 14(1), 56-64. 
Farah Faadillah Herindraningrum dan Indrawati Yuhertiana : Kualitas Laporan Keuangan Pemerintah Daerah Di Indonesia : Literature Review

Yuliati, R., Yuliansyah, Y., \& Adelina, Y. E. (2019). The implementation of accrual basis accounting by Indonesia's local governments. International Review of Public Administration, 24(2), 67-80. 